УАK 342.8

ББК 67.400 .8

DOI 10.22394/1682-2358-2017-5-60-67

I.S. Alekbina, Candidate of Sciences (Law), Docent of the Legal Studies Department, North-West Institute of Management, Branch of the Russian Presidential Academy of $\mathrm{Na}$ tional Economy and Public Administration, 3rd Class State Counsellor of Saint-Petersburz

\section{SUSTAINABILITY OF SUBJECTIVE RIGHTS IN THE ELECTORAL LAW}

The evolution of legislative clearance of the active and passive electoral rights is studied. It is noted that in recent years the terms of subjective electoral rights have been repeatedly changed. It is concluded that active electoral right is more sustainable as there have only been a few clarifications.

Key words and word-combinations: subjective electoral rights, evolution of law, principles of electoral law, restrictions on voting rights.
И.С. Алёхина, кандидат юридиеских наук, дочент кафедрь правоведения Северо-Западного института управления - филиала Российской академии народного хозяйства и государственной служби при Президенте РФ (email: i.s.alebina@yandex.ru)

\section{УСТОЙЧИВОСТЬ СУБЪЕКТИВНЫХ ПРАВ В ИЗБИРАТЕАЬНОМ ПРАВЕ}

\begin{abstract}
Аннотация. Исследуется эволюция законодательного оформления активного и пассивного избирательного права. Отмечается, что условия предоставления субъективных избирательных прав за последние годы неоднократно претерпевали изменения. Делаются выводы о большей устойчивости активного избирательного права, в отношении которого было лишь несколько уточнений.

Ключевые слова и словосочетания: субъективное избирательное право, эволюция права, принципы избирательного права, ограничения избирательных прав.
\end{abstract}

И сследуя эволющию изменений законодательного оформления активного и пассивного избирательного права после принятия в 2002 г. Фелерацьного закона «О6 основных гарантиях избирательных прав и права на участие в референдуме гражАан Российской Федерации» от 12 июня 2002 г. № 67-фз, отметим, что $\Lambda$.А. НуАненко, А.А. Тхабисимовой анализировалось развитие избирательного законодательства в России [1, с. 7; 2; 3] ; Т.А. Коломейџевой, А.А. Григорьевой исследовалась история 
становления принципов избирательного права [4] ; И.В. Минникес рассматривалась история становления и развития принципа обязательности выборов в российском избирательном праве и электорацьной практике X начала XX в. [5] ; к вопросу стабицьности норм избирательного права обращался в своей работе Е.В. Мотлохов [6] . Большинство исследователей анацизируют главным образом историю становления, развития и законодательного закрепления принџипов избирательного права, а также принџипов организации и проведения выборов в России за последние сто мет. Не рассматривая в Аанной публикации соотношение понятий «изменчивость», «стабильность», «устойчивость», обратим внимание, что законодательное оформление субъективных избирательных прав за последние годы неоднократно претерпевамо изменения.

В законодательном оформиении активного избирательного права можно отметить его определенную «устойчивость»: за последние 23 года существенных изменений, кроме небольшого уточнения, в отечественное законодательство в отношении предоставления гражданам Российской Федерации активного избирательного права не вносилось. ОАнако преАпринимались попытки оспорить основания ограничения активного избирательного права в отношении миц, находящихся в местах мишения свободы по приговору суда, [7] и в 2016 г. Аанная норма стала предметом рассмотрения Конституџионного Суаа РФ [8].

При более глубоком изучении законодательного оформления пассивного избирательного права в России трудно заявцять о его «устойчивости». Проанализируем «эволющию» изменений, которые были внесены в пассивное избирательное право после принятия Федерального закона «Об основных гарантиях избирательных прав и права на участие в референдуме граждан Российской Федерации» от 12 июня 2002 г. (в реА. от 1 июня 2017 г.) № 67-ф3.

В первоначальной редакции п. 1 ст. 4 указанного Закона гражданину Российской Федерации по Аостижении определенного возраста предоставцялось право быть избранным в органы государственной вцасти и органы местного самоуправления. В дальнейшем законодатель уточнил терминологию и установиц, что пассивное избирательное право предоставляется дия избрания депутатом законодательного (преАставительного) органа государственной власти, выборным Аолжностным Аиџом [9; 10] .

В 2016 г. в Аанный пункт быми внесены поправки [11], уточняющие норму, определяющую достижение возраста предоставления избирательного права: «гражланин Российской Федерации, достигший на день голосования возраста 18 мет...», а также возраста, по достижении которого гражАанин может принять участие в действиях по подготовке и проведению референдума. Ао принятия этой нормы, когда в законе было написано, что «гражданин Российской Федерации, достигший возраста 18 мет, имеет право избирать, быть избран...», в научной митературе неоднократно поднимацся вопрос: «Что означает понятие “избран”? Когда наступает возможность принимать участие в избирательных действиях? Если 18 мет наступает ко 
Аню голосования ици по достижении 18 мет к моменту совершения этих Аействий? Например, начать собирать подписи с того Аня, когАа наступимо совершеннолетие? Можно ми выдвинуть кандидатуру на выборах мицу, которому 18 мет исполнится после окончания периода выдвижения и регистрации, то есть ко Аню голосования? ИАи понятие «избирать» относится только к проџедуре голосования и выражается в получении бюлметеня и выражении своего мнения путем голосования?». Практика проведения будущих избирательных кампаний покажет, останется ки данный вопрос открытым или уйдет в прошлое. Отметим, что в отношении наступления пассивного избирательного права также были приняты уточнения: кандиАатом на АОлжность высшего Аолжностного миџа субъекта РФ может быть выдвинут гражданин Российской Федераџии, достигший на день голосования возраста 30 мет [10].

С принятием этой нормы, в совокупности с п. 28 ст. 2 рассматриваемого Федерального закона, в котором зафиксировано, что «избирательные права гражАан - конституџионное право гражАан Российской Федерации избирать и быть избранными в органы государственной власти и органы местного самоуправления, а также право участвовать в выдвижении кандидатов, списков кандидатов, в предвыборной агитации, в наблюдении за проведением выборов, работой избирательных комиссий, включая установление итогов голосования и определение результатов выборов, в Аругих избирательных действиях в порядке, установленном Конституџией Российской Федерации... иными... законами», можно $\Lambda и$ говорить о прекращении дискуссии о предоставлении права принимать участие в выдвижении кандидатов миџам, которым в период выдвижения еще нет 18 мет и которые достигнут 18 мет на день голосования? Отметим, что в п. 6 ст. 48 указанного Закона установлено, что «запрещается привлекать к предвыборной агитации, агитации по вопросам референдума миџ, не Аостигших на день голосования возраста 18 мет, в том числе использовать изображения и высказывания таких миџ в агитаџионных материалах», а в 2016 г. уточнено, что граждане, признанные судом недееспособными или содержащиеся в местах мишения свободы по приговору суда, не только не имеют права избирать и быть избранными, участвовать в референдуме, «но и осушествцять Аругие избирательные действия». Аополнения в п. 3 ст. 4 были внесены в 2016 г. [11].

Неизменным остается правовое регулирование принципа всеобшего избирательного права в части предоставления гражданину Российской Федерации права избирать, быть избранным, участвовать в референдуме независимо от пола, расы, наџиональности, языка, происхождения, имущественного и Аолжностного положения, места жкительства, отношения к религии, убеждений, принадмежности к общественным объединениям, а также Аругих обстоятельств.

Значительные изменения в законодательство вносились в отношении пассивного избирательного права, ограничивающие права желающих быть избранными.Так, новемлой 2006 г. бымо ограничено право быть избранными в отношении граждан Российской Федерации, имеющих гражданство иност- 
ранного государства Аибо виА на жительство или иной документ, подтвержАающий право на постоянное проживание гражданина Российской Федерации на территории иностранного государства. Указанные граждане вправе быть избранными в органы местного самоуправления, если это преАусмотрено международным договором Российской Федераџии [12]. В настоящее время действуют международные договоры с четырьмя странами: Республикой Бемарусь, Республикой Туркменистан, Киргизской Республикой и Республикой Таджикистан.

В 2006 г., ограничения пассивного избирательного права были законоАательно установлены и в отношении отдельных категорий граждан, осужденных к мишению свободы за совершение тяжких и (ими) особо тяжких преступлений и имеющих на день голосования на выборах неснятую и непогашенную судимость за указанные преступления [13]. В 2012 г. редакция данного пункта была изменена на следующую формулировку: «...осужденные когда-либо к мишению свободы за совершение тяжких и (или) особо тяжких преступцений, за исключением случаев, когда в соответствии с новым уголовным законом эти деяния не признаются тяжкими или особо тяжкими преступмениями». В 2013 г. постановлением Конституционного Суда РФ положения данного пункта были признаны не соответствующими Конституции РФ, а федеральному законодателю было предписано внести изменения в «подпункт “а” пункта 3.2 статьи 4» Федерального закона «Об основных гарантиях избиратемьных прав и права на участие в референдуме граждан РФ» с учетом правовых позиций, выраженных в постановлении Конституционного Суда РФ. В 2014 г. [14] текст был «возврашен» к редакции 2006 г. [15] .

В 2014 г. введены ограничения пассивного избирательного права в отношении следующих категорий киџ:

- осужденных за совершение преступлений экстремистской направленности, предусмотренных Уголовным кодексом РФ и имеющих на день гоцосования на выборах неснятую и непогашенную судимость за указанные преступления (при этом на Аанных Аиџ не распространяются цишение права баммотироваться в течение опредеменного периода времени) [15];

- подвергнутых административному наказанию за совершение административного правонарушения, преАусмотренного статьей 20.3 [13] (про-

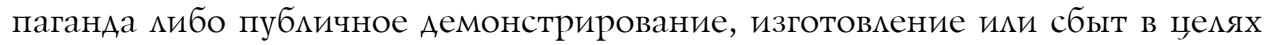
пропаганды мибо приобретение в цемях сбыта или пропаганды нацистской атрибутики или символики, Аибо атрибутики или символики экстремист-

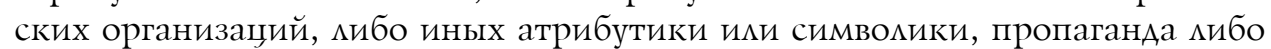
пубцичное демонстрирование которых запрещены федерацьными законами);

- подвергнутых административному наказанию за совершение административного правонарушения, предусмотренного ст. 20.29 [16] (производство и распространение экстремистских материалов) КоАП РФ, если голосование на выборах состоится до окончания срока, в течение которого миџо считается подвергнутым административному наказанию. 
Ограничения были установлены в отношении таких участников избирательных правоотношений, как гражданин, кандидат, избирательное объединение, в отношении которых вступившим в сику решением суда установмен факт, свидетельствующий о том, что указанный субъект избирательных правоотношений в своих выступлениях на публичных мероприятиях, в СМИ или в распространяемых им материалах (в том числе размещаемых в информационно-телекоммуникационных сетях, доступ к которым не ограничен определенным кругом Аиџ, включая Интернет) призывал к совершению определенных деяний:

экстремистской деятельности кибо иным способом побужАал к подобным деяниям, обосновывац или оправдывац экстремизм;

совершал действия, направленные на возбуждение соџиальной, расовой, национальной или религиозной розни, унижение национального достоинства, пропагандУ искАючительности, превосходства Аибо неПолноџенности гражАан по признаку их отношения к религии, соџиальной, расовой, национальной, религиозной или языковой принадмежности;

пропагандировал и публично демонстрировал нацистскую атрибутику или символику Аибо атрибутику или символику, сходные с нацистской атрибутикой или символикой до степени их смешения.

При этом должно соблюдаться условие, что указанные нарушения мибо действия совершены до Аня голосования на выборах в течение установленного законом срока полномочий органа государственной власти или органа мест-

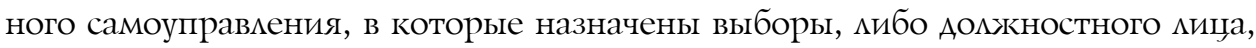
Аля избрания которого назначены выборы.

В 2014 г. были приняты нормы, устанавливающие ограничения пассивного избирательного права некоторых категорий граждан Российской Федерации. Так, осужденные к мишению свободы за совершение тяжких пре-

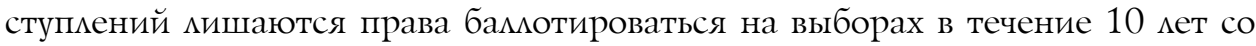
Аня снятия или погашения судимости, а особо тяжких преступлений - в течение 15 мет [15]. Если срок действия указанных ограничений пассивного избирательного права истекает в период избирательной кампании до Аня голосования на выборах, гражданин, пассивное избирательное право которого было ограничено, вправе в установленном законом порядке быть выдвинутым кандидатом на этих выборах [15]. Если деяние, за совершение которого бым осужден гражданин, в соответствии с новым уголовным законом не признается тяжким или особо тяжким преступлением, действие указанных ограничений пассивного избирательного права прекращается со дня вступцения в сицу этого уголовного закона [15]. Если тяжкое преступцение, за совершение которого был осужден гражданин, в соответствии с новым уголовным законом признается особо тяжким преступлением или если особо тяжкое преступцение, за совершение которого был осужден гражданин, в соответствии с новым уголовным законом признается тяжким преступмением, указанные ограничения действуют до истечения десяти мет со дня снятия ици погашения судимости [15]. 
В связи с отменой прямых выборов глав субъектов РФ менялась и формулировка п. 8 ст. 4 в части отмены в 2004 и возвращении в 2012 г. возрастного ценза (Аостижения 30 мет) при избрании глав субъектов Российской Федераџии. По сути, установленный 30-летний ценз Аля глав субъектов Российской Федерации не меняляя, но эта норма была «перенесена» из Федерального закона № 67-Ф3 «Об основных гарантиях...» в Федеральный закон «Об общих принщипах организации законодательных (представительных) и исполнительных органов государственной власти субъектов Российской Федераџии» [17], где был установмен порядок надемения полномочиями главы субъекта законодательным (представительным) органом субъекта Российской Федерации по преАставлению Президента Российской Федерации.

Кроме перечисленного, были уточнены формулировки норм, связанных со статусом депутата, работающего на постоянной основе, а также выборного Аолжностного мица, касающиеся установменных законом ограничений финансирования преподавательской, научной и иной творческой Аеятельности искцючительно за счет средств иностранных государств, международных и иностранных организаџий, иностранных граждан и киџ без гражданства [18] .

Таким образом, можно сделать вывод, что условия предоставления субъективного избирательного права за последние годы неоднократно претерпевали изменения. В эволюции законодательного оформления активного избирательного права можно отметить несколько важных уточнений. В одном указывалось, что гражданин обладает избирательным правом при достижении 18-летнего возраста на день голосования; в другом конкретизировалось, что отдельные категории граждан Российской Федерации (недееспособные и миџа, находящиеся в местах мишения свободы по приговору суда) не имеют права участвовать в избирательных действиях.

В части законодательного оформления пассивного избирательного права законодателем неоднократно принимались уточнения и изменения, касавшиеся уточнения возраста, по достижении которого гражданин мог принять участие в избирательных действиях с целью реализовать свое пассивное избирательное право; ограничения пассивного избирательного права, в отношении граждан Российской Федерации, имеющих гражданство иностранного государства, а также вид на жительство в иностранном государстве, равно как и проживание в иностранном государстве. Были приняты изменения, мишавшие пассивного избирательного праваосужденных к мишению свободы за совершение тяжких и (или) особо тяжких преступлений и имеющих на день голосования на выборах неснятую и непогашенную судимость за указанные преступления (первоначально предложенная законодатемем формулировка цишала права принять участие в выборах граждан, осужденных когда-либо к цишению свободы за совершение тяжких и (или) особо тяжких преступлений, за исключением случаев, когда в соответствии с новым уголовным законом эти деяния не признаются тяжкими или особо тяжкими преступлениями). В дальнейшем на основании правовой позиции Консти- 
туционного СуАа РФ были установлены сроки ограничения пассивного избирательного права в отношении указанной категорий граждан Российской Федерации: осужденные к мишению свободы за совершение тяжких преступлений цишаются права бамлотироваться на выборах в течение 10 мет со Аня снятия или погашения судимости, а особо тяжких преступмений - в течение 15 мет. Быми также введены ограничения пассивного избирательного права в отношении осужденных за совершение преступяений экстремистской направленности, предусмотренных УК РФ, а также в отношении миџ, подвергнутых административному наказанию за совершение административного правонарушения.

Таким образом, активное избирательное право можно назвать более стабильным, так как в его отношении было оформлено мишь несколько уточнений; законодательное же оформление пассивного избирательного права неоднократно подвергалось уточнениям и изменениям, поэтому его сложно опредемять как «устойчивое».

\section{Библиографический список}

1. Нудненко Л.А., Тхабисимова Л.А. Развитие избирательного законодательства в России с 1993 по 2014 годы // Актуальные проблемы российского права. 2015. № 1.

2. Нудненко Л.А. Развитие законодательства о пассивном избирательном праве в России в период с 1937 по 1988 г. // История государства и права. 2015. № 10. С. 44-47.

3. Нудненко Л.А. Развитие избирательного законодательства России в период с 1905 по 1917 г. // Конституционное и муниципальное право. 2015. № 9. С. 70-76.

4. Коломейщева T.A., Григорьева А.А. История становления принципов избирательного права // Евразийский союз ученых. 2016. № 4-4 (25). С. 83-85.

5. Минникес И.В. Принцип обязательности выборов: историко-правовой анализ // Пролог: журнал о праве. 2013. № 1 (1). С. 6-13.

6. Мотлохов E.B. К вопросу о стабильности норм избирательного права Российской Федерации // Наука и образование в глобальных процессах: материалы Международной научнопрактической конференции. / отв. ред. Т.С. Искужин. 2014. С. 122-125.

7. Дело «Анчугов и Гладков (Anchugov and Gladkov) против Российской Федерации» (жалоба № 11157/04, 15162/05): постановление ЕСПЧ от 4 июля 2013 г. URL: http://www. garant.ru/products/ipo/prime/doc/70539826/

8. По делу о разрешении вопроса о возможности исполнения в соответствии с Конституцией Российской Федерации постановления Европейского Суда по правам человека от 4 июля 2013 года по делу «Анчугов и Гладков против России» в связи с запросом Министерства юстиции РФ: постановление Конституционного Суда РФ от 19 апр. 2016 г. № 12-П. URL: http://legalacts.ru/doc/postanovlenie-konstitutsionnogo-suda-rf-ot-19042016-n/

9. О внесении изменений в статью 3 приложения к Федеральному закону «Об обеспечении конституционных прав граждан Российской Федерации избирать и быть избранными в органы местного самоуправления» и статью 4 Федерального закона «Об основных гарантиях избирательных прав и права на участие в референдуме граждан Российской Федерации»: Федер. закон от 9 нояб. 2009 г. № 250-Ф3. URL: http://www.consultant.ru/document/cons_doc LAW_93465/

10. О внесении изменений в Федеральный закон «Об общих принципах организации законодательных (представительных) и исполнительных органов государственной власти субъектов Российской Федерации» и Федеральный закон «Об основных гарантиях изби- 
рательных прав и права на участие в референдуме граждан Российской Федерации: Федер. закон от 2 мая 2012 г. № 40-Ф3. URL: http://www.consultant.ru/document/cons_doc_LAW_ 129119

11. О внесении изменений в отдельные законодательные акты Российской Федерации о выборах и референдумах и иные законодательные акты Российской Федерации: Федер. закон от 9 марта 2016 г. № 66-Ф3. URL: http://www.consultant.ru/document/cons_doc_LAW_ $194895 /$

12. О внесении изменений в отдельные законодательные акты Российской Федерации в части уточнения требований к замещению государственных и муниципальных должностей: Федер. закон от 25 июля 2006 г. № 128-Ф3. URL: http://www.consultant.ru/document/cons_doc LAW 61756/

13. О внесении изменений в Федеральный закон «Об основных гарантиях избирательных прав и права на участие в референдуме граждан Российской Федерации» и Гражданский процессуальный кодекс Российской Федерации: Федер. закон от 5 дек. 2006 г. № 225-Ф3 URL: http://www.consultant.ru/document/cons_doc_LAW_64321/

14. О внесении изменений в отдельные законодательные акты Российской Федерации: Федер. закон от 21 февр. 2014 г. № 19-Ф3. URL: http://www.consultant.ru/document/cons_doc_ LAW 159348/

15. По делу о проверке конституционности подпункта «а» пункта 3.2 статьи 4 Федерального закона «Об основных гарантиях избирательных прав и права на участие в референдуме граждан Российской Федерации, части первой статьи 10 и части шестой статьи 86 Уголовного кодекса Российской Федерации в связи с жалобами граждан Г.Б. Егорова, А.Л. Казакова, И.Ю. Кравцова, А.В. Куприянова, А.С. Латыпова и В.Ю. Синькова: постановление Конституционного Суда РФ от 10 окт. 2013 г. № 20-П. URL: http://www.consultant.ru/document/cons doc_LAW_153235/

16. О внесении изменений в отдельные законодательные акты Российской Федерации в связи с совершенствованием государственного управления в области противодействия экстремизму: Федер. закон от 24 июля 2007 г. № 211-Ф3. URL: http:/www.consultant.ru/document/ cons_doc_LAW_52146/

17. Об общих принципах организации законодательных (представительных) и исполнительных органов государственной власти субъектов Российской Федерации: Федер. закон от 6 окт. 1999 г. № 184-Ф3. URL: http://www.consultant.ru/document/cons_doc_LAW_ $14058 /$

18. О внесении изменений в законодательные акты Российской Федерации о выборах и референдумах и иные законодательные акты Российской Федерации: Федер. закон от 21 июля 2005 г. № 93-Ф3. URL: http://www.consultant.ru/document/cons_doc_LAW_54573/ 